\title{
GREEN SYNTHESIS NANOPARTIKEL PERAK MENGGUNAKAN EKSTRAK DAUN PUCUK IDAT (Cratoxylum glaucum) SEBAGAI BIOREDUKTOR
}

\author{
Verry Andre Fabiani*, Febry Sutanti, Desti Silvia, Megawati Ayu Putri \\ Jurusan Kimia, Fakultas Teknik, Universitas Bangka Belitung \\ Corresponding author: verry-andre@ubb.ac.id
}

\begin{tabular}{l}
\hline ARTICLE INFO \\
Article history: \\
Received 18 July 2018 \\
Accepted 30 December \\
2018 \\
Available online \\
30 December 2018 \\
Keywords: \\
particle size, pucuk \\
idat, Scherrer formula, \\
silver nanoparticle, \\
reducing agent
\end{tabular}

1. Pendahuluan

Kepulauan Bangka Belitung memiliki berbagai tanaman endemik yang potensial untuk dikembangkan. Salah satu tanaman yang menarik untuk diteliti yaitu tanaman pucuk idat (Cratoxylum glaucum). Tanaman ini tumbuh pada lahan terbuka dengan intensitas matahari yang tinggi. Pucuk idat sangat dikenal oleh masyarakat di Bangka Belitung karena sering dimanfaatkan sebagai penyedap masakan. Bagian tanaman pucuk idat yang diolah masyarakat yaitu pada daunnya. Daun pucuk idat mengandung banyak senyawa antioksidan, metabolit sekunder mayor yang ditemukan pada daun pucuk idat meliputi flavonoid dan tanin ${ }^{[1]}$. Senyawa tersebut berupa fenolik yang secara teoritis memiliki sifat pereduksi sehingga dapat digunakan sebagai bioreduktor pada sintesis nanopartikel perak ${ }^{[2]}$.

Nanopartikel merupakan suatu partikel berukuran nano sekitar 1-100 nm. Material dengan struktur nanopartikel umumnya memiliki sifat yang berbeda dengan struktur aslinya. Berbagai sifat tersebut dapat dimodifikasi melalui pengontrolan ukuran partikel, pengaturan komposisi kimia, modifikasi permukaan, dan pengontrolan interaksi antar partikel ${ }^{[3-4] . ~ B e r b a g a i ~ j e n i s ~}$ nanopartikel saat ini telah banyak disintesis seperti nanopartikel emas, perak, besi ,zink, dan logam oksida ${ }^{[5]}$. Nanopartikel perak (NPP) memiliki keunggulan dibandingkan dengan nanopartikel emas karena sifat optis NPP lebih baik ${ }^{[6],}$ sehingga NPP dapat digunakan sebagai 
detektor dan sekaligus sebagai indikator pewarnaan (kolorimetri). Selain itu nanopartikel perak telah banyak digunakan pada pakaian, alas kaki, cat, perban, peralatan rumah tangga, kosmetik, dan plastik karena memiliki sifat antibakteri ${ }^{[7]}$.

Nanopartikel perak dapat disintesis dengan metode fisika, kimia dan biologi. Meskipun metode fisika dan kimia menghasilkan partikel yang murni, namun metode tersebut mahal dan tidak ramah lingkungan. Sehingga metode biologi dipilih dengan menggunakan reduktor ekstrak tanaman ${ }^{[8-14]}$. Metode ini merupakan metode sintesis nanopartikel yang ramah lingkungan karena mampu meminimalisir penggunaan bahan-bahan anorganik yang berbahaya dan sekaligus limbahnya sehingga lebih dikenal dengan bioreduktor ${ }^{[4] .}$ Penelitian sebelumnya telah menggunakan ekstrak daun manggis, daun gambir, daun sirih, dan daun ketapang ${ }^{[15-18]}$ sebagai bioreduktor dalam sintesis nanopartikel perak, sehingga dihasilkan partikel berukuran yang ratarata dibawah $100 \mathrm{~nm}$ dengan struktur spherical ${ }^{[19-20]}$.

Pada penelitian ini dilakukan sintesis nanopartikel perak menggunakan ekstrak daun pucuk idat (Cratoxylum glaucum). Sintesis nanopartikel perak dilakukan dengan mereaksikan ekstrak pucuk idat dan larutan perak nitrat $\left(\mathrm{AgNO}_{3}\right)$ 0,05 M (1:2) melalui proses pengadukan selama 24 jam. Karakteristik nanopartikel perak dianalisis dengan UV-Vis, XRD dan SEM.

\section{Metode}

\subsection{Bahan dan Alat}

Bahan yang digunakan dalam penelitian ini yaitu akuades, aseton teknis, ekstrak pucuk idat dan perak nitrat $\left(\mathrm{AgNO}_{3}\right)$ Merck. Alat yang digunakan dalam penelitian ini yaitu, hotplate, oven, neraca analitik, peralatan gelas, Fourier Transform Infra Red (FTIR) Shimadzu, Spektrofotometer UV-Vis SPECORD 210 PLUS - 223F1936C dan X-Ray Diffraction PANalytical.

\subsection{Prosedur penelitian}

\section{Preparasi Daun Pucuk Idat}

Daun pucuk idat dibersihkan dan kemudian dikeringkan dengan cara diangin-anginkan pada suhu kamar. Daun yang telah kering dipotong hingga berukuran kecil kemudian dihaluskan dengan blender. Serbuk daun pucuk idat disimpan dalam wadah yang bersih dan terlindung dari cahaya agar tidak terjadi kerusakan dan penuruan mutu.

\section{Ekstraksi Daun Pucuk Idat}

Sebanyak 20 gram serbuk daun pucuk idat dicampurkan ke dalam $100 \mathrm{~mL}$ akuades, selanjutnya direbus hingga mendidih. Campuran kemudian didinginkan dan disaring untuk memisahkan filtrat dan residunya. Filtrat yang diperoleh kemudian disimpan dalam wadah bersih dan tertutup untuk kemudian digunakan sebagai bioreduktor pada sintesis nanopartikel perak.

\section{Sintesis Nanopartikel Perak}

Sebanyak $20 \mathrm{~mL}$ ekstrak pucuk idat dicampurkan kedalam $40 \mathrm{~mL}$ larutan $\mathrm{AgNO}_{3}$ 0,05 M. Campuran diaduk dengan magnetic stirer selama 24 jam pada suhu ruang hingga membentuk endapan. Setelah pengadukan selesai, campuran disentrifuge dengan kecepatan $3500 \mathrm{rpm}$ selama 10 menit. Hasil sentrifuge kemudian diperoleh filtrat dan endapan. Endapan dikeringkan dalam oven pada suhu $80^{\circ} \mathrm{C}$ selama 2 jam. Endapan yang telah kering kemudian digerus hingga halus dan ditimbang. Filtrat yang diperoleh dilakukan analisis UV-Vis untuk mengidentifikasi terbentuknya nanopartikel perak. Kemudian endapan dianalisis dengan XRD untuk melihat derajat kristalinitas dan menghitung ukuran partikel melalui persamaan Scherrer serta analisis SEM untuk mengamati bentuk morfologi nanopartikel perak.

\section{Hasil dan Diskusi}

\subsection{Ekstraksi Daun Pucuk Idat}

Pada penelitian ini, ekstraksi daun pucuk idat dilakukan menggunakan pelarut air. Pemilihan pelarut air disebabkan karena lebih ekonomis, mudah diperoleh, tidak menguap, tidak beracun, tidak 
mudah terbakar dan stabil. Selain itu, pelarut air merupakan pelarut yang baik untuk ekstraksi senyawa dengan berat molekul rendah seperti flavonoid ${ }^{[21] . ~ U n t u k ~ m e m p e r k u a t ~ h a l ~ t e r s e b u t ~ m a k a ~}$ dilakukan analisis FTIR pada ekstrak pucuk idat.

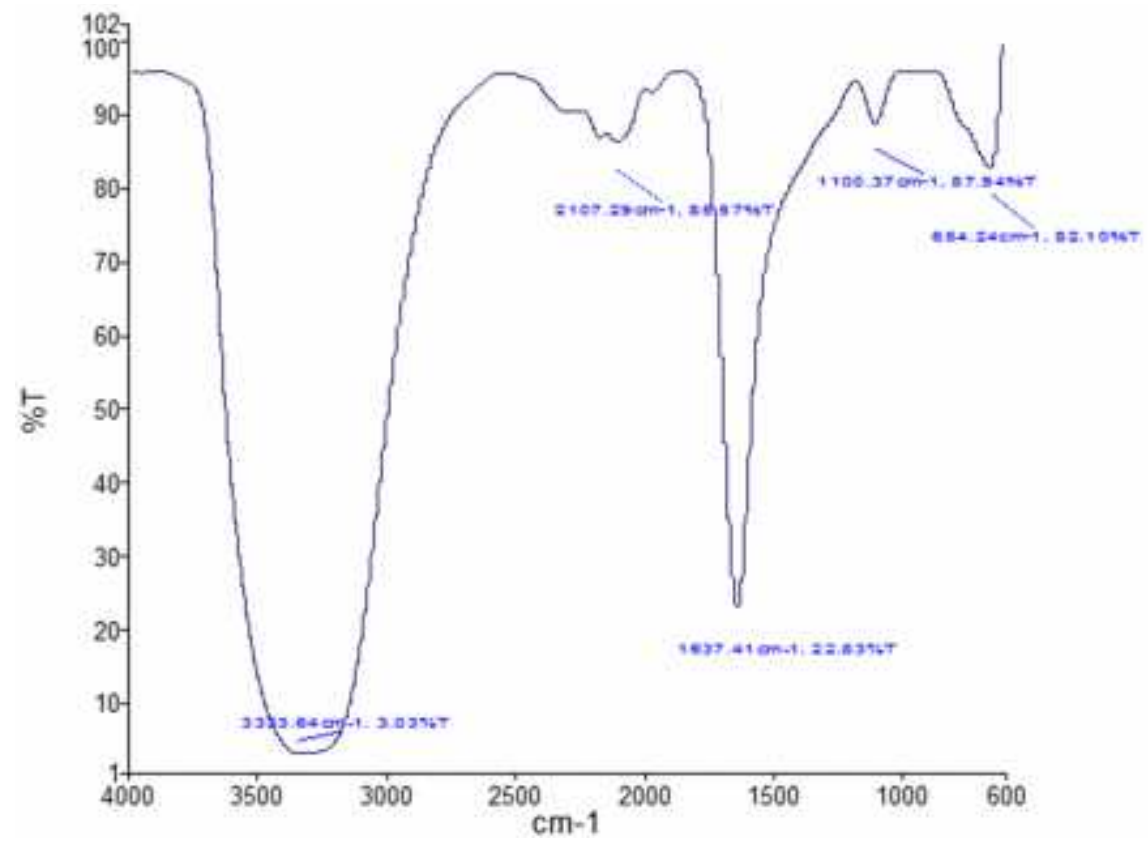

Gambar 1. Spektrum FTIR Ekstrak Daun Pucuk Idat

Berdasarkan spektrum FTIR pada ekstrak pucuk idat (Gambar 1) dapat diamati bahwa terdapat serapan pada daerah bilangan gelombang $3333,64 \mathrm{~cm}^{-1}$ yang menunjukan gugus fungsi $-\mathrm{OH}^{[22]}$. Menurut Gurunathan et al. ${ }^{[23]}$ ion hidroksida diperlukan untuk mempercepat proses reduksi ion $\mathrm{Ag}^{+}$ pada sintesis nanopartikel perak. Selain itu terdapat serapan pada daerah $2107,29 \mathrm{~cm}^{-1}$ dan 1637,41 $\mathrm{cm}^{-1}$ yang masing-masing menunjukkan adanya gugus $-\mathrm{C}-\mathrm{O}$ dan $-\mathrm{C}=\mathrm{O}^{[22]}$, Berdasarkan hasil analisis FTIR dapat disimpulkan bahwa adanya gugus hidroksil dan karbonil mengindikasikan adanya senyawa flavonoid dan tanin pada ekstrak daun pucuk idat.

\subsection{Sintesis Nanopartikel Perak}

Nanopartikel Perak (NPP) telah banyak digunakan dalam berbagai aplikasi pada dunia medis maupun produk rumah tangga karena sifatnya sebagai antibakteri. Sintesis NPP menggunakan ekstrak tanaman merupakan salah satu metode green synthesis yang dapat meminimalisir

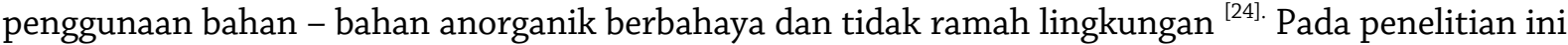
digunakan ekstrak pucuk idat sebagai bioreduktor pada sintesis nanopartikel perak (NPP). Prinsip kerja tanaman dalam mereduksi NPP adalah kemampuan senyawa pada tanaman yang mampu

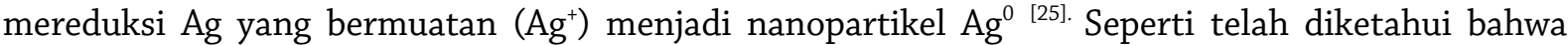
logam Ag memiliki satu muatan positif, untuk membuat nanopartikel logam perak dan kemudian tereduksi menjadi $\mathrm{Ag}^{0}$ dengan bantuan ekstrak tanaman sebagai reduktor. Proses reduksi pada pembentukan nanopartikel perak disebabkan adanya senyawa metabolit sekunder pada daun pucuk idat yaitu senyawa fenolik seperti flavonoid dan tanin. Senyawa tanin merupakan salah satu senyawa metabolit sekunder dari pucuk idat yang mengalami oksidasi dan $\mathrm{Ag}^{+}$pada $\mathrm{AgNO}_{3}$ yang mengalami reduksi menjadi $\mathrm{Ag}^{0}$, sehingga dalam pembuatan nanopartikel perak (NPP) reaksi yang terjadi merupakan reaksi redoks (Gambar 2) ${ }^{[26]}$. 


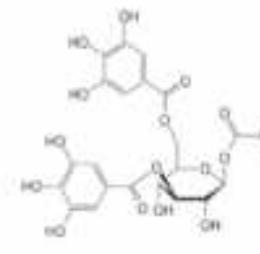

(a)

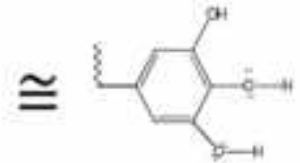

(b)

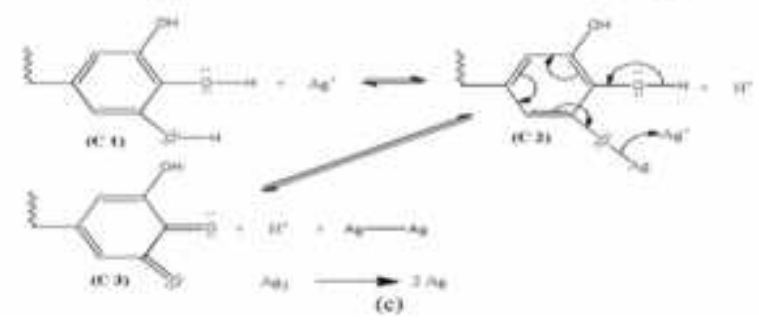

Gambar 2. Struktur Molekul (a)Tanin, (b) Struktur Sederhana dari Tanin, (c) Mekanisme Reaksi Kemungkinan Pembentukan NPP ${ }^{[27]}$

Sumber Ag yang digunakan pada penelitian ini yaitu perak nitrat $\left(\mathrm{AgNO}_{3}\right)$ 0,05 $\mathrm{M}$ yang kemudian direaksikan dengan ekstrak pucuk idat. Menurut penelitian Arief dkk ${ }^{[16]}$, larutan $\mathrm{AgNO}_{3}$ dengan konsentrasi 0,05 M merupakan konsentrasi optimum untuk menghasilkan rendemen yang besar. Semakin besar konsentrasi perak nitrat maka proses reduksi akan semakin cepat. Hal ini diakibatkan ion Ag dalam larutan makin banyak dan pereduksi alami tidak sulit dalam melakukan interaksi atau berikatan dengan ion Ag. Endapan yang diperoleh berwarna coklat keabuan (Gambar 3) yang mengindikasikan terbentuknya nanopartikel ${ }^{[28]}$.

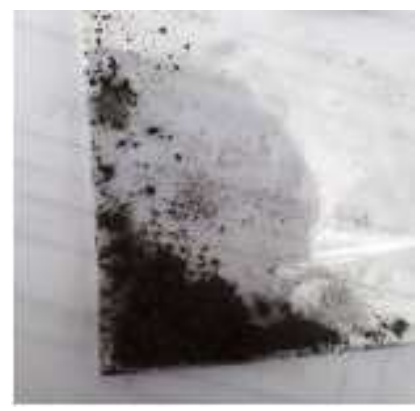

Gambar 3. Padatan Nanopartikel Perak

Pada sintesis nanopartikel perak terjadi pembentukan polimer perak dan kemudian terhidrolisis membentuk inti perak ${ }^{[29]}$. Inti perak muncul dalam kondisi jenuh sehingga menyebabkan terbentuknya koloid seperti dijelaskan pada Gambar 4.

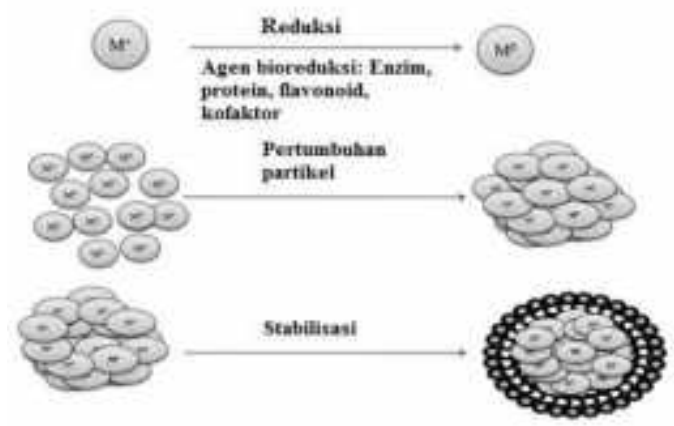

Gambar 4. Skema reduksi, pertumbuhan dan pembentukan nanopartikel ${ }^{[29]}$ 


\subsection{Karakterisasi Nanopartikel Perak}

\subsubsection{Analisis Perubahan Warna}

Pada saat proses pencampuran larutan $\mathrm{AgNO}_{3}$ dengan ekstrak pucuk idat, warna larutan yang semula berwarna kuning kemudian setelah 30 menit didiamkan tampak warna larutan menjadi kecoklatan dan menjadi keabuan setelah 24 jam (Gambar 5). Perubahan warna tersebut merupakan salah satu indikator terbentuknya nanopartikel perak karena telah terjadinya proses reduksi ion perak $^{[30]}$.
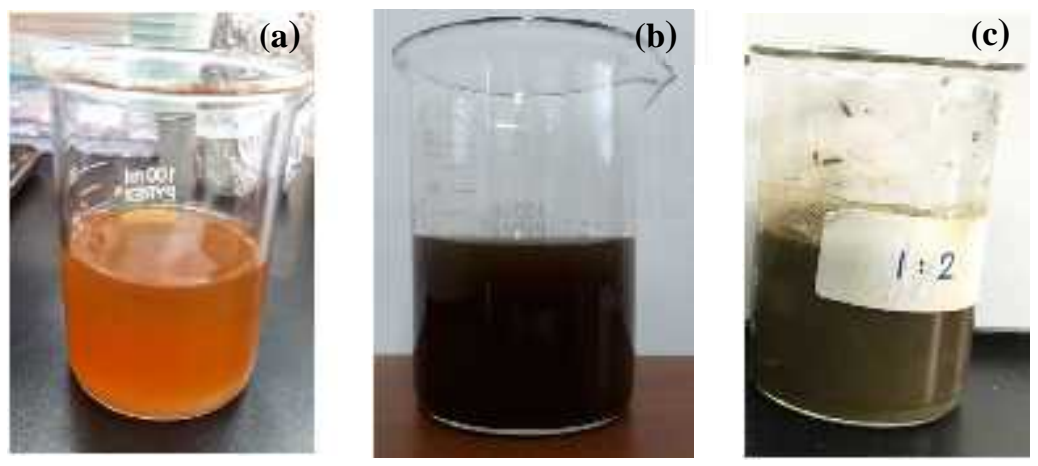

Gambar 5. Warna larutan saat didiamkan pada waktu (a) 0 Menit (b) 30 menit dan (c) setelah pengadukan 24 jam

Sintesis nanopartikel perak dilakukan dengan metode pengadukan menggunakan magnetic stirrer selama 24 jam. Setelah pengadukan, larutan yang semula berwarna kecoklatan kemudian berubah menjadi warna coklat keabuan yang disertai adanya endapan. Pengadukan yang kontinu selama proses sintesis dapat memengaruhi kecepatan dan jumlah nanopartikel perak yang dihasilkan. Pengadukan juga mampu mempercepat terjadinya reaksi serta dapat menghomogenkan larutan. Proses tersebut juga mampu mencegah terjadi agregasi antar nanopartikel sehingga terdistribusi merata didalam larutan ${ }^{[31] .}$

\subsubsection{Analisis Spektrofotometer UV-Vis}

Salah satu analisis untuk mengidentifikasi terbentuknya nanopartikel yaitu analisis spektrofotometer UV-Vis. Analisis spektrofotometer UV-Vis digunakan untuk analisis kualitatif atau kuantitatif pada suatu senyawa. Absorpsi cahaya ultraviolet maupun cahaya tampak mengakibatkan terjadinya transisi elektron dimana elektron-elektron dari orbital dasar berenergi rendah ke orbital keadaan tereksitasi berenergi lebih tinggi. Radiasi ultraviolet maupun sinar tampak dapat diserap tergantung pada transisi elektron. Molekul-molekul yang membutuhkan banyak energi untuk transisi elektron, akan menyerap pada panjang gelombang yang lebih pendek sedangankan molekul yang membutuhkan sedikit energi akan menyerap panjang gelombang yang lebih panjang ${ }^{[32]}$.

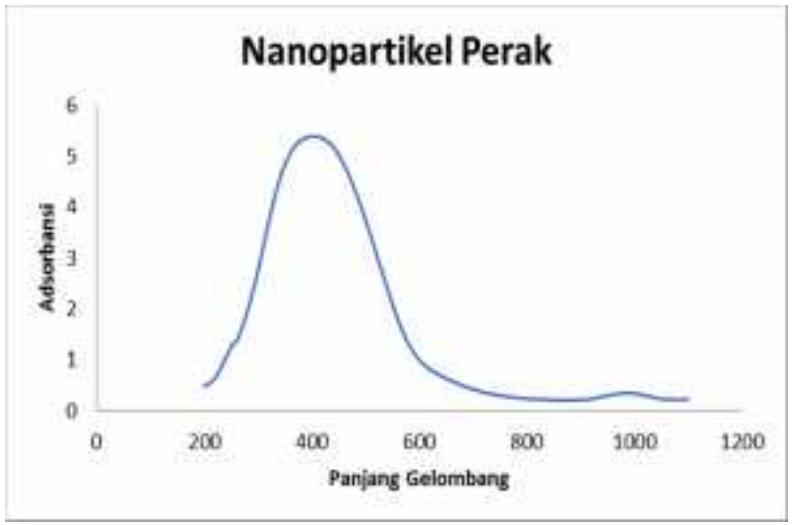

Gambar 6. Spektrum UV-Vis Nanopartikel Perak 
Berdasarkan hasil analisis Spektrofotometer UV-Vis (Gambar 6), serapan panjang gelombang maksimum untuk nanopartikel perak yaitu $405 \mathrm{~nm}$. Pada panjang gelombang 395-405 nm mengindikasikan terbentuknya nanopartikel perak dengan ukuran $10-14 \mathrm{~nm}^{[33] \text {. }}$

\subsubsection{Analisis XRD}

Karakterisasi XRD dilakukan untuk mendapatkan informasi derajat kristalinitas (penentuan struktur kristal-amorf) dan orientasi (hkl) serta dapat menentukan ukuran kristal menggunakan persamaan Scherrer pada identifikasi pola difraksi dan intensitas puncak ${ }^{[27]}$. Difraktogram nanopartikel perak dapat dilihat pada Gambar 7.

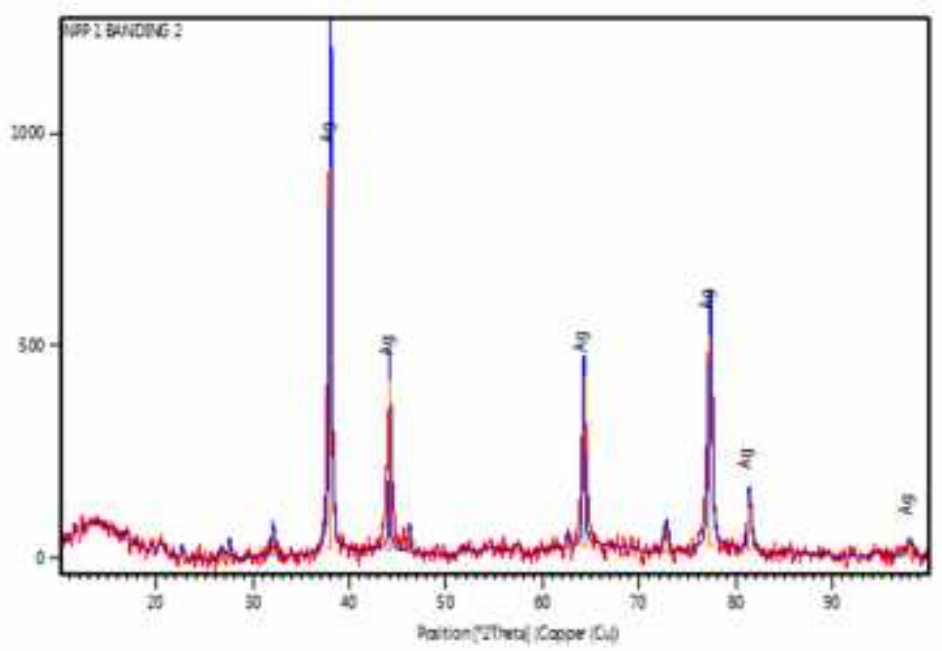

Gambar 7. Difraktogram XRD Nanopartikel Perak (merah) dan standar Ag (biru)

Puncak-puncak pola difraksi nanopartikel perak dengan jelas ditunjukkan pada nilai $2 \theta$ yaitu $37,99^{\circ}$, $44,10^{\circ}, 64,23^{\circ}$ dan $77,26^{\circ}$ dengan nilai FWHM (Full Width at Half Maximum) masing-masing 0,0053, 0,0031, 0,004, 0,0066. Menurut database pada International Centre for Diffraction Data (ICDD No. 01071-4613), pola difraksi nanopartikel perak terdapat pada puncak difraksi $38,09^{\circ}, 44,27^{\circ}, 64,41^{\circ}$ dan $77,35^{\circ}$ yang ditunjukkan dengan indeks Miller (111), (200), (220), dan (311). Berdasarkan database ICDD, hasil pengukuran XRD menunjukkan adanya kesesuaian pola difraksi dengan referensi sehingga dapat disimpulkan pada sampel penelitian ini terbentuk nanopartikel perak dengan sistem kristal kubik. Hasil analisa XRD selain digunakan untuk menentukan struktur kristal dalam sampel, juga dapat digunakan untuk mengetahui ukuran kristal nanopartikel perak menggunakan persamaan Scherrer.

$$
D=\frac{K \lambda}{\beta \cos \theta}
$$

dimana :

$\mathrm{D}=$ ukuran partikel (nm)

$$
\begin{aligned}
& \lambda=\text { panjang gelombang } \mathrm{Cu}-\mathrm{K} \alpha(1,5406 \AA) \\
& \beta=\text { FWHM (rad) } \quad \theta=\text { sudut Bragg }(\mathrm{rad})
\end{aligned}
$$

Tabel 1. Hasil Data XRD Nanopartikel Perak

\begin{tabular}{cccc}
\hline $\mathbf{2 \theta}(\mathbf{d e g})$ & $\boldsymbol{\theta}$ (rad) & FWHM (rad) & D (nm) \\
\hline 37,9901 & 0,3315 & 0,0053 & 27,35 \\
44,1076 & 0,3849 & 0,0031 & 47,83 \\
64,239 & 0,5605 & 0,004 & 40,71 \\
77,2618 & 0,6742 & 0,0066 & 26,48 \\
\hline \multicolumn{3}{c}{ Ukuran Partikel (D) Rata-rata } & $\mathbf{3 5 , 5 9}$ \\
\hline
\end{tabular}


Berdasarkan hasil perhitungan menggunakan persamaan Scherrer diperoleh rata-rata ukuran nanopartikel perak yaitu $35,59 \mathrm{~nm}$

\subsubsection{Analisis SEM}

Nanopartikel perak hasil sintesis dikarakterisasi dengan instrument Scanning Electron Microscopy (SEM). Analisis SEM bertujuan untuk mengetahui morfologi nanopartikel perak.
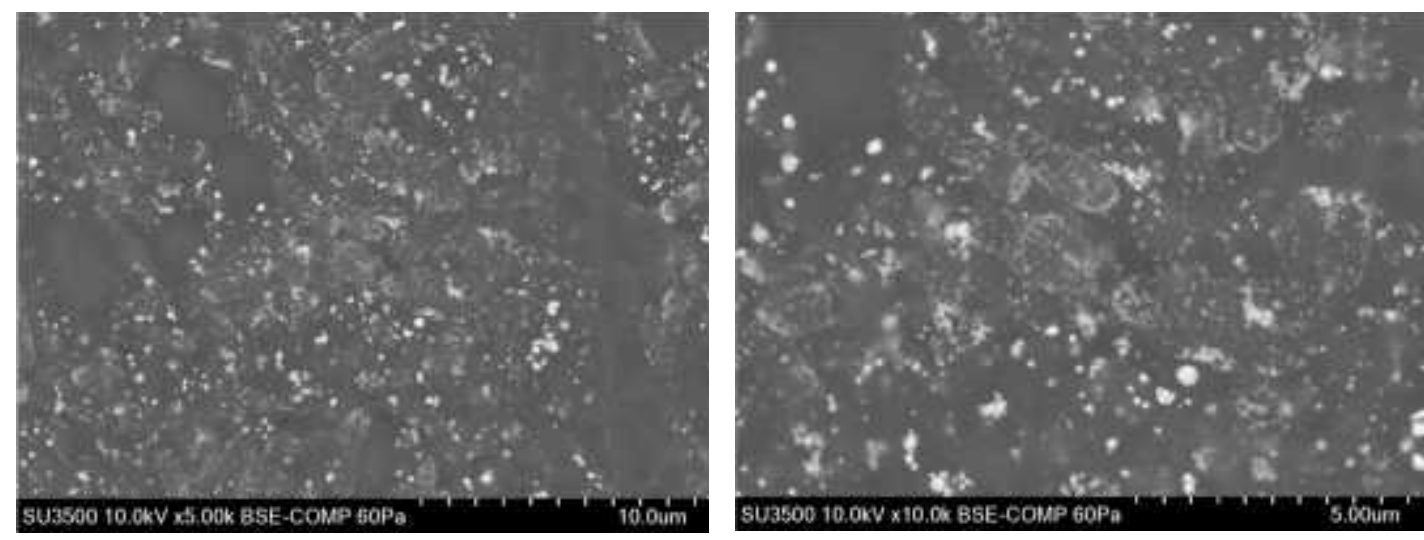

Gambar 8. Morfologi Nanopartikel Perak

Gambar 8 menunjukkan bahwa nanopartikel perak hasil sintesis memiliki bentuk acak dan beberapa berbentuk spherical dengan ukuran yang bervariasi akibat efek dari agregasi nanopartikel ${ }^{[15]}$.

\section{KESIMPULAN}

Daun pucuk idat (Cratoxylum glaucum) dapat digunakan sebagai bioreduktor dalam sintesis nanopartikel perak. Metode penelitian dilakukan dengan mereaksikan ekstrak pucuk idat dan larutan $\mathrm{AgNO}_{3}$ 0,05 M (1:2) melalui proses pengadukan selama 24 jam. Karakteristik nanopartikel perak dapat diamati dari perubahan warna kuning hingga coklat keabuan yang disertai endapan, selain itu berdasarkan analisis UV-Vis menunjukkan serapan pada panjang gelombang $405 \mathrm{~nm}$. Karakterisasi XRD menunjukkan adanya kesesuaian dengan pola difraksi nanopartikel referensi dan diperoleh ukuran partikel rata-rata menggunakan persamaan Scherrer yaitu 35,59 nm. Morfologi nanopartikel perak memiliki bentuk yang acak dan beberapa spherical akibat efek agregasi nanopartikel.

\section{UCAPAN TERIMAKASIH}

Ucapan terimakasih diberikan kepada DIKTI atas bantuan dana penelitian melalui skim Program Kreatifitas Mahasiwa Bidang Penelitian Tahun 2018.

\section{DAFTAR PUSTAKA}

[1] Mahardika, RG dan Roanisca, O. 2018., Antioxidant Activity and Phytochemical of Extract Ethyl Acetat Pucuk Idat (Cratoxylum Glaucum), Indo. J. Chem. Res, 5(2), 481-486 (2018)

[2] Philip, D., Green Synthesis of Gold and Silver Nanoparticles Using Hibiscus rosasinensis, Physica E. 42(5): 1417- 1424 (2010).

[3] Bandyopandhyay, A.K., Nano Material, New Age International Ltd, New Delhi (2008).

[4] Feldheim, D.L and Foss, C.A Jr., Metal nanoparticles ; Sinthesis, characterization and Applications. Marcel Dekker Inc. Switzerland (2002). 
[5] Prasad, S.B., Current Understanding of Synthesis and Pharmacological Aspects of Silver Nanoparticles, American Journal of Phytomedicine and Clinical Therapeutics, 1(7): 536-547 (2013).

[6] Caro, C., Castillo, P.M., Klippstein, R., Pozo, D., Zaderenko, A.P. Silver Nanoparticles: Sensing and Imaging Application. University of Seville-UPO-Junta the andalucia-spain, (2010).

[7] Oldenburg, S.J., 2014, Silver Nanoparticles: Properties and Applications. (Online): www.sigmaaldrich.com/materi alsscience/nanomaterials/silvernanoparticles.html. diakses tanggal 10 Juli 2018 (2014).

[8] Sastry.M, Ahmad. A, Khan. M, and Kumar. R, Microbial nanoparticle production, in Nanobiotechnology, ed. by Niemeyer CM and Mirkin CA. Wiley-VCH, Weinheim, 126, (2004).

[9] Bhattacharya D, Rajinder G, Nanotechnology and potential of microorganisms, Crit Rev Biotechnol, 25:199-204, (2005).

[10] Mohanpuria P, Rana Nisha K and Yadav SK, Biosynthesis of nanoparticles: technological concepts and future applications, Journal of Nanoparticle Research 10:507-517, (2008).

[11] Li, L., C. Liu, Z. Liu, R. Tsao and S. Liu, Identification of phenylethanoid glycosides in plant extract of Plantago asiatica L. by liquid chromatography-electrospray ionization mass spectrometry, Chinese J. Chem. $27: 541-545$, (2009).

[12] Vera-Montenegro. Y, F. Ibarra-Velarde, G. Ramirez-Avila and J. Munguia-Xochihua, In vitro fasciolicide activity of some plant extracts against newly excysted flukes, Ann. New York Acad. Sci., 1149:180-182, (2008).

[13] Prabhu, N., T.R. Divya and G. Yamuna, Synthesis of silver phyto nanoparticles and their antibacterial efficacy, Digest J. Nanomater. Biostruct., 5 : 185-189, (2010).

[14] Padmadhas, R. and R. Ragunathan, Effect of lead nano particle present in the leaf of Calotrphis Gigantea which result in the loss of the painted grass hoppe of the Western ghats species in India.Int, J. Nanotechnol. Appl., 3 : 89-96, (2009).

[15] Masakke, Y, Rasyid M, Sulfikar, Biosintesis Nanopartikel Perak Menggunakan Ekstrak Metanol Daun Manggis (Garcinia mangostana L.). Jurnal Chemica 15 (2): 45 - 57 (2014).

[16] Arief, S. Rahma, W. Wellia, D.V. Zulhadjri., Green Synthesis Nanopartikel Ag dengan Menggunakan Ekstrak Gambir Sebagai Bioreduktor. Prosiding Semirata 2015 Bidang Mipa BksPtn Barat. Universitas Tanjungpura, Pontianak. 233 - 238 (2015).

[17] Purnamasari, M.D., Sintesis Antibakteri Nanopartikel Perak Menggunakan Bioreduktor Ekstrak Daun Sirih (Piper betle linn) dengan Irradiasi Microwave, Skripsi, Jurusan Kimia FMIPA Universitas Negeri Semarang (2015).

[18] Lembang E.Y, Maming, M. Zaki, Sintesis Nanopartikel Perak Dengan Metode Reduksi Menggunakan Bioreduktor Ekstrak Daun Ketapang (Terminalia catappa), Repository UNHAS (2013).

[19] Leela A, Vivekanandan M., Tapping the Unexploited Plant Resources for the Synthesis of Silver Nanoparticles. African Journal of Biotechnology, 7(17):3162-3165 (2008).

[20] Zargar M, Hamid, A. A., Bakar, F. A., Shamsudin, M. N., Shameli K, Jahanshiri F, Farahani F, Green Synthesis and Antibacterial Effect of Silver Nanoparticles Using Vitex Negundo L. Article Molecules, 16: 6667-6676 (2011).

[21] Wijesekera, ROB, The Medicinal Plant Industry, Washington DC : CRC Press, pp. 85-90 (1991).

[22] Skoog, D. A., Holler, E. J., Crouch, S. R., Principles of Instrumental Analysis. Thomson Higher Education. USA. Pp. 848-851 (2007).

[23] Gurunathan S, Kalimuthu K, Ramanathan V, Venkataraman D, Sureshbabu RKP, Jeyaraj M, Nellaiah H, \& Soo HE, Biosynthesis, purification, and characterization of silver nanoparticles using E. coli. Colloids and surface B: Biointerfaces 74: 328-335 (2009).

[24] Thakkar, K.N., Mathre, S.S., dan Parikh, N.Y., Biological synthesis of metallic nanoparticle. Nanomedicine: nanotechnology, biology and medicine, 6, 257- 262 (2010).

[25] Kumar, V., Yadav, S. K., Plantmediated synthesis of silver and gol nanoparticles and their application, J. Chem. Technol. Biotechnol. 84: 151- 157 (2009).

[26] Shankar, S. S., Rai, A., Ahmad A., \& Sastry,M.., Rapid synthesis of Au, Ag,and bimetallic Au core-Ag shell nanoparticles using Neem (Azadirachta indica) leaf broth, J. Colloid Interface Sci., 275(4): 496-502 (2004). 
[27] Payapo, I.A, Zakir, M., Soekamto, N.H., Sintesis Nanopartikel Perak Menggunakan Ekstrak Daun Ketapang (Terminalia catappa) dan Potensinya sebagai Tabir Surya, Repository UNHAS (2016).

[28] Yugandhar. P, Savithramma. N, Biosynthesis, characterization and antimicrobial studies of green synthesized silver nanoparticles from fruit extract of Syzygium alternifolium (Wt.) Walp. an endemic, endangered medicinal tree taxon, Appl Nanosci 6:223-233 (2015).

[29] Fatimah, Is., Nur Afisa Lintang Mutiara, 2016. Biosynthesis of silver nanoparticles using putri malu (Mimosa pudica) leaves extract and microwave irradiation method. Jurnal Molekul 11 (2) : 288-298 (2016).

[30] Sankar NS, Dipak P, Nilu H, Dipta S, Samir KP, Green synthesis of silver nanoparticles using fresh water green alga Pithophora oedogonia (Mont.) Wittrock and evaluation of their antibacterial activity. Appl Nanosci 5:703-709 (2014).

[31] Matutu JM, Maming dan Taba P., Sintesis Nanopartikel Perak dengan Metode Reduksi Menggunakan Buah Merah (Pandanus Conoideus) Sebagai Bioreduktor. Jurusan Kimia FMIPA UNHAS (2016).

[32] Amiruddin, M.A. dan Titik Taufikurrohmah., 2013, Sintesis dan Karakterisasi Nanopartikel Emas menggunakan Matriks Bentonit sebagai Material Peredam Radikal Bebas dalam Kosmetik. Journal of Chemistry. 2(1): 68- 75 (2013).

[33] Solomon SD, Mozghan Bahadory, Aravindan V. Jeyarajasingam, Susan A. Rutkowsky, and Charles Boritz, Synthesis and Study of Silver Nanoparticles, Journal of Chemical Education, 84(2): 322-325 (2007). 